УДК 159.923:324-051:001.891

DOI https://doi.org/10.26661/2310-4368/2021-1-1

\title{
ТЕОРЕТИЧНІ ПІДСТАВИ ДЛЯ ТИПОЛОГІЗАЦІЇ ЕЛЕКТОРАТУ В СОЦІЛЬНО-ПСИХОЛОГІЧНОМУ ПІДХОДІ
}

\author{
Безрукова К. М. \\ аспірантка кафедри соиіальної психологї \\ факультету психології \\ Київський начіональний університет імені Тараса Шевченка \\ вул. Володимирська, 60, Київ, Украӥна \\ orcid.org/0000-0002-6230-8348 \\ kateryna.bezrukova@gmail.com
} Ключові слова: електорат,
електоральні групи, типологія
електорату, критерії
типологізації електорату,
соціально-психологічний підхід.
У статті здійснено спробу систематизації та узагальнення наявних теоретичних підходів до типологізації електорату, виділено та проаналізовано основні підстави для типологізації виборців. Доведено, що електорат $є$ предметом міждисциплінарних досліджень, який формується на перетині політології, соціології та психології, тому автором проаналізовано основні теоретичні підходи до визначення поняття «електоральна група» в межах цих наукових напрямів. Під час аналізу класичних теорій електоральної поведінки в статті розглянуто основні теоретичні підходи до типологізації електорату. Критеріями для типологізації в них виступають політичні симпатії та орієнтації, міра знайомства 3 програмами кандидатів i агітаційною продукцією, зміна наміру голосувати під час передвиборчої кампанії, ступінь залученості у виборчий процес, стійкість електоральних орієнтацій, міра власної вигоди від результатів виборів, чутливість до базових стратегій виборчих кампаній. Приділено увагу обгрунтуванню соціальнопсихологічних критеріїв типологізації виборців, закладених послідовниками Мічиганської школи, які виділяли партійну ідентифікацію, ставлення до поточних подій і до кандидата як ключові підстави для типологізації.

На прикладі аналізу основних підходів автором доведено, що спроби типологізувати електорат за психологічними характеристиками в роботах багатьох учених мають фрагментарний характер, найчастіше враховуючи лише одну 3 цих характеристик без охоплення всієї можливої кількості змінних. Акцентовано, що найбільш поширеною в країнах пострадянського простору й досі залишається типологізація виборців на підставі соціальнодемографічних характеристик, за якою групи виділяються на основі віку, статі, рівня освіти, регіону проживання та типу поселення, політичної належності, електоральних симпатій. 


\title{
THEORETICAL GROUNDS FOR TYPOLOGIZATION OF THE ELECTORATE IN THE SOCIO-PSYCHOLOGICAL APPROACH
}

\author{
Bezrukova K. M. \\ Postgraduate Student at the Department of Social Psychology \\ of the Faculty of Psychology \\ Taras Shevchenko National University of Kyiv \\ Volodymyrska str., 60, Kyiv, Ukraine \\ orcid.org/0000-0002-6230-8348 \\ kateryna.bezrukova@gmail.com
}

\begin{abstract}
Key words: electorate, electoral groups, typology of the electorate, criteria for typologization of electorate, socio-psychological approach.
\end{abstract}

\begin{abstract}
The article attempts to systematize and generalize the existing theoretical approaches to typologization of the electorate, to identifies and analyzes the main grounds for typologization of voters. It is proved that the electorate is the subject of interdisciplinary research, which is formed at the intersection of political science, sociology and psychology, so the author analyzes the main theoretical approaches to defining the concept of "electoral group" within these areas. Analyzing the classical theories of electoral behavior, the article considers the main theoretical approaches to typologization of the electorate. Criteria for typologization are political sympathies and orientations, the degree of acquaintance with the programs of candidates and campaign products, changing of intention to vote during the election campaign, the degree of involvement in the election process, the stability of electoral orientations, the degree of self-benefit from election strategies campaigns. Attention is paid to the substantiation of socio-psychological criteria of voter typologization, laid down by followers of the Michigan school, who singled out party identification, attitude to current events and to the candidate as key grounds for development of typology.

On the example of the analysis of the main approaches the author proved that attempts to typologize the electorate by psychological characteristics in the works of many scientists are fragmentary, often taking into account only one of these characteristics without covering all possible variables. It is emphasized that the most common in the post-Soviet countries is still the typology of voters based on socio-demographic characteristics, according to which groups are distinguished on the basis of age, gender, level of education, region and type of settlement, political affiliation, electoral sympathies.
\end{abstract}

Постановка проблеми. Одним із найважливіших завдань виборчої кампанії будь-якого політика є цілеспрямована робота з тими виборцями, від яких найбільшою мірою залежить розширення його електоральної бази. Практичний інтерес для політичних консультантів сьогодні становить наукове та теоретичне обгрунтування ефективності політичної комунікації, налагодження якої під час практичного застосування можливе лише за умови наявності детальних і психологічно вивірених уявлень про цільову аудиторію - тобто про типи українських виборців та їхні соціально-психологічні особливості.

Успіх американських і британських електоральних досліджень зі створення психологічних портретів виборців спонукав українських дослідників до більш глибинного вивчення відомих під- ходів до типологізації електорату, їх аналізу та адаптації до сучасних реалій.

Саме через те, що електорат являє собою групу зі складною, не завжди очевидною й ситуативно змінною структурою, чимало психологів отримують можливість знайти в ній власний аспект, власний предмет дослідження. Стан наукових доробок у межах політичної, соціальної та диференційної психології дає нам змогу розглядати електорат як специфічну складно структуровану групу, яку можливо розділити на підгрупи, беручи за основу визначені для диференціації критерії.

Зазвичай в одному дослідженні типологізація електорату відбувається на підставі 1-3 відносно незалежних диспозицій без охоплення всієї можливої кількості змінних і занурення в суб'єктивні характеристики виборця. Єдиного інтегратив- 
ного підходу до типологізації електорату в науці нині немає.

Серед досліджень соціально-психологічних особливостей виборців і підстав для виділення в структурі електорату специфічних груп можна виділити роботи П. Лазарсфельда [3], М. Фіорини [4], Г. Дилигенського [14], К. Холодковського [12], О. Вишняка [11], О. Полторака [10], В. Рибаченка [16], В. Комаровскього [1], В. Зарубіна [2], С. Хорошаєва [18], Є. Галицької [7], К. Бура і О. Левцун [17] та інших.

Мета статті - систематизувати та узагальнити уявлення про відомі підходи до типологізації електорату, виділити та проаналізувати основні підстави для типологізації виборців.

Виклад основного матеріалу дослідження. Електорат $є$ предметом міждисциплінарних досліджень, який формується на перетині трьох наук політології, соціології та психології. А отже, можна говорити про три основні теоретичні підходи до визначення поняття «електоральна група».

У політологічній традиції електоральні групи близькі політичним партіям за функціями і засобами впливу. Вони формуються на основі усвідомлення людьми необхідності спільної діяльності для реалізації своїх інтересів. Визначаються електоральні групи як добровільні об'єднання, що формуються 3 метою висловлення і відстоювання політично значимих інтересів людей, що до них входять у взаєминах 3 державою та іншими політичними інститутами.

Підставою для формування цих груп політологи вважають економічні, соціальні, культурні, етнічні, релігійні, ідеологічні потреби. Прикладом таких груп виступають профспілкові об'єднання, об'єднання підприємців, спілки споживачів, екологічні рухи, жіночі, молодіжні та інші асоціації, недержавні культурно-просвітницькі організації, благодійні товариства, тощо.

Основне призначення таких груп полягає в агрегації та артикуляції інтересів. Отже, електоральні групи виступають механізмом реалізації прав людини і втіленням суті громадянського суспільства в політичній системі.

На нашу думку, електоральні групи не обов'язково мають бути об'єднаними однією метою чи включені в спільну діяльність, рух. Люди з однієі електоральної групи можуть бути незнайомими і не мати жодної спільної формальної приналежності.

У соціології електоральні групи існують здебільшого для фіксації результатів електоральних досліджень. Вони виділяються на основі соціально-демографічних критеріїв - віку, статі, рівня освіти, регіону проживання та типу поселення, політичної приналежності, електоральних симпатій, тощо. Тобто найбільшу питому вагу мають саме об'єктивні показники.
Такий підхід, на нашу думку, не враховує індивідуальних особливостей членів електоральної групи. Таким чином в групу, наприклад, жінок 25-45 років з вищою освітою, середнім достатком 3 одного регіону можуть потрапити люди абсолютно полярні за своїми політичними вподобаннями та ціннісними орієнтаціями.

Психологія намагається осягнути суб'єктивні характеристики членів електоральних груп, тому підставами для типологізації виступають психічні якості виборців, риси їх характеру, когнітивні та емоційні прояви електорального вибору, тощо.

Одну з перших спроб типологізації виборців за часів Радянського Союзу зробив В. Комаровский [1]. У дослідженні виборців після виборів народних депутатів СРСР, результати якого були опубліковані в 1990 році, автор розглядає три групи виборців:

1. Група людей, що не брали участі в виборах.

2. Група тих, хто голосував проти всіх внесених до списку кандидатів.

3. Група тих, хто голосував за одного (або кількох) кандидатів.

З обраними за об' сктивними характеристиками групами автор намагається пов'язати суб'єктивні характеристики виборців, що складають данні групи. Він типологізує виборців за їх мірою знайомства 3 програмами кандидатів і агітаційною продукцією, за критерієм зміни наміру голосувати у ході передвиборчої кампанії.

Автор зазначає, що класифікація (типологізація) виборців повинна мати щонайменше однією 3 підстав політичні симпатії і орієнтації виборців. Тому, на основі соціологічного опитування виділяє ще три категорії виборців: групу тих, хто на майбутніх виборах орієнтуються на представників місцевих партійних і радянських органів; тих, хто готовий віддати перевагу інтелігенції, незалежним претендентам і лідерам неформальних організацій; тих, хто орієнтується на робочих і селян.

Однак за результатом дослідження виявлені категорії виборців лише частково збігаються 3 описаними вище групами. «Групи не проглядаються як доступне для огляду компактне ціле. Вони добре виділяються по одним параметрам, по іншим проглядається їх внутрішня неоднорідність. Потрібен час, щоб знайти більш чіткі орієнтири, що піддаються надійній емпіричній інтерпретації» [1].

Обгрунтовуючи результати досліджень, В. Комаровский називає обрані критерії не універсальними, наголошує на необхідності в більш диференційованому вигляді уявити підгрупу активної більшості та важливості не просто зафіксувати особливості поведінки тієї чи іншої групи виборців, а й з'ясувати, які чинники іiї зумовили. 
«Це ставить перед дослідниками складне завдання пошуку критеріїв класифікації і типологізації виборців, для визначення їх політичних симпатій i прогнозу їх поведінки на виборах» [1].

Велика кількість сучасних досліджень електорального поля все ж вдається до подальшої типологізації виборців за критерієм виду їх електоральної поведінки. Групування електорату за цим критерієм (на виборців, що приймають участь у виборах; виборців, що прийшли до виборчих дільниць, але зіпсували бюлетень; виборців, що проголосували проти всіх кандидатів та виборців, які не брали участь у голосуванні) й досі можна зустріти у сучасних дослідженнях.

Російський дослідник В. Зарубін доповнив наведений підхід типологією елективних груп за ступенем включеності у виборчій процес [2, с.29.]. Автор розділив електорат так:

1. Виборці-активісти: послідовні та непослідовні. Обидві підгрупи приймають участь у виборах на всіх рівнях, але перші відрізняються цікавістю до передвиборчої кампанії та позитивною оцінкою значимості голосування. Непослідовні виборці-активісти не проявляють інтересу до виборчих перегонів та не вважають результати важливими для себе.

2. Виборці з хиткими уподобаннями - беруть участь не у всіх виборах.

3. Виборці-абсентеїсти. У цій групі у послідовних виборців-абсентеїстів відсутній інтерес до кампанії і позитивна оцінка значення результатів виборів. Непослідовні виборці-абсентеїсти, навпаки, проявляють інтерес до передвиборчої кампанії і вважають результати важливими для себе.

П. Лазерфельд під час типологізації виборців керується ступенем стійкості їх електоральних орієнтацій [3]. Врешті, дослідник розділяє виборців на три великих групи:

1. Стабільні виборці.

2. Непостійні виборці.

3. Виборці, що змінюють партії.

М. Фіорина говорить про «ретроспективного виборця», який на думку дослідника, оцінює минулі дії влади та, переглядаючи минулий досвід, оновлює власні оцінки партій і політиків [4]. С. Попкін виділяє «колективних вкладників», які голосують в ім'я загального блага та «приватних інвесторів», які орієнтуються переважно на власні вигоди від результатів голосування [5].

За спостереженнями дослідника О. Петрова, типологізувати електорат можна за чутливістю до базових стратегій виборчих кампаній. Автор виділяє наступні стратегії комунікації: «програмна» стратегія, «апаратна» стратегія, «проблемна» стратегія, «соціально-економічна» стратегія, «рекламна» стратегія, «лідерська» стратегія, «адресна» чи «диференційована» стратегія [6].
Варто зазначити, що нині в Україні та пострадянських країнах Свропи домінантним підходом є типологізація виборців на підставі географічних і соціально-демографічних критеріїв. Таке бачення електорального поля можна зустріти чи не в кожному сучасному дослідженні з електоральної проблематики. Критерієм типологізації тут виступають вік, стать, рівень освіти, матеріальний стан, тип поселення та регіон проживання виборців. За умов використання даного підходу, електоральні групи формуються на основі наведених критеріїв.

Показовим прикладом практичної роботи 3 такою типологізацією є дослідження Є. Галицької та А. Чернякова [7]. Для кожного з претендентів на перемогу у виборах було спеціальним чином побудовано розбиття населення на соціально-демографічні групи з метою пошуку груп, у яких певний політик мав найбільший рейтинг.

Під час виділення груп враховувалися такі п’ять соціально-демографічних показників: стать, вік, освіта, регіон і тип місця проживання респондента. Дослідники намагалися серед закладений критеріїв знайти показники, які певним чином впливають на рейтинг політиків та розділити виборців на найбільш контрастні групи.

Індикатором ступеня електоральної підтримки стали частка голосуючих за даного політика (\% від населення) i рейтинг політика в групі (\% голосуючих за нього в групі). За цим індикатором було виділено три типи груп - 3 високою, помірною і слабкою електоральною підтримкою. Крім того, по кожній електоральній групі наводилася їі питома вага (\%) в загальній чисельності дорослого населення країни. Таким чином дослідники отримали більш деталізовану та розгорнуту картину електоральних рейтингів політиків [7].

Ще одним прикладом використання саме соціально-демографічної типологізації електорату у практичній діяльності є комплексна методика реконфігурації електорального поля [8]. У найбільш загальному вигляді цей підхід можна описати як істотне збільшення числа контрольованих параметрів виборчої кампанії та перерозподілення електоральних рейтингів.

Підготовчий етап характеризується тим, що окрім отриманих соціологічних даних, більш детально аналізується імідж кандидата та його електоральна ніша. За допомогою аналізу параметрів конфігурації електорального поля, дослідник отримує інформацію про симпатиків усіх представлених кандидатів, що дозволяє визначати, за допомогою яких факторів відбувається прийняття рішення про електоральний вибір.

Природно, що найважливішим завданням, яке розв'язує ця методика, є досягнення адресності впливу через здійснення його лише всередині необхідної електоральної ніші або групи. Для 
розв'язання цього завдання використовуються ізольовані канали комунікації, які охоплюють лише конкретну електоральну групу та форми комунікації, прийнятні лише для неї [8].

Головним недоліком соціологічного підходу при вивченні електоральної поведінки i, зокрема, типологізації електорату, вважається пояснення здійснення електорального вибору, засноване виключно на основі аналізу соціологічних чинників, а саме почуття близькості до певної політичної сили та наміру раціонально використати свій голос. Поза увагою залишається аналіз дій електоральних акторів, недооцінюється вплив засобів масової комунікації на формування електорального рішення, не аналізуються мотиви участі в голосуванні різних категорій виборців та динаміка абсентеїзму. Поза полем зору дослідників залишається особистість виборця.

На думку послідовників Мічиганської школи (Т. Адорно, Г. Айзенка, Г. Олпорта, Е. Фромма, С. Томкінса та ін.) [9], електоральна поведінка людини визначається взаємодією трьох складових: партійна ідентифікація, ставлення до поточних подій, ставлення до кандидата. Прихильники цього підходу вважають, що саме партійна ідентифікація як найстабільніша із зазначених характеристик, впливає на інші змінні й на кінцевий вибір під час голосування. В основі інтересу до політичної партії, на думку дослідників, лежить не класова позиція, не освіта, не національність чи релігія, а процеси політичної соціалізації, що діють безпосередньо через родину, визначаючи партійну ідентифікацію [10].

Ця парадигма показує свою високу дієвість у США. Дослідження електорату країн 3 двопартійною системою та високою ідеологічною сформованістю партій дійсно виявляють високі показники ідентифікації електорату з цінностями партій та навіть спадкоємність політичних поглядів. Однак, практично не пояснено як працює механізм партійної ідентифікації в країнах з мультипартійною системою.

Як зазначають дослідники [11], у більшості політичних партій в Україні немає чіткої ідеологічної спрямованості, а програмні положення всіх політичних партій у галузі внутрішньої політики дуже схожі. На перший погляд вплив партійної ідентифікації на електоральний вибір українських громадян незначний, оскільки лише $35 \%$ iз них вважає, що в сучасному політикумі є рухи, коаліції, партії, близькі їм за програмними цілями та ідеологічними поглядами [11]. Динаміка ідеологічної ідентифікації громадян, представлена за період незалежності України, також підтверджує дану тенденцію [11].

Окрім того, українські дослідники стверджують, що в нашій країні виборці віддають свої голоси не за політичні сили, а за конкретні особистості, що їх представляють. Тому типологізувати електорат за критерієм політичної ідентичності, як це заведено в соціально-психологічному підході, на нашу думку, не $\epsilon$ ефективним у сучасних умовах. Результати досліджень електорату Росії К. Холодковського показують схожі тенденції. Автор упевнений, що ідейно-політичні відмінності в установках як партій, так і електорату, поступово розмиваються [12].

Свого часу дослідження Л. Гудкова та Б. Дубіна, присвячені аналізу виборів 1999 року, продемонстрували, що відмінності електорального вибору громадян були майже несуттєвими: «несуттєво більший акцент на необхідності соціальної підтримки населення, більше протекціонізму і захисту вітчизняного виробника - у прихильників комуністів, трохи більше вимог свободи ринку від державного контролю і захисту власності у прибічників «правих». От практично і усі розбіжності, вони в нюансах, в величині та ступені настійності відповідних очікувань» [13].

Дослідження К. Холодковського спирається на наступну позицію. У кожної партії зазвичай $€$ «типовий» виборець, який наділений особливими соціальними та демографічними характеристиками. Соціальна однорідність навіть ядра партійного електорату відносна, але, разом $з$ тим, стійка соціально-демографічна специфіка $є$ одним з суттєвих показників «невипадковості» електорату партії, iii масової бази. Подібно до того, як кожна партія має власний «типовий» електорат, основні соціально-демографічні групи характеризуються власними партійно-політичними уподобаннями [12].

Отже, автор виходить на опис за соціально-демографічними критеріями «типових» електоратів партій та на розподілення симпатій певних електоральних груп між політичними силами. Однак найбільш психологізованою характеристикою, якою керується дослідник під час опису виборців, є динаміка соціального оптимізму та відмінності ціннісних орієнтацій. Автор підкреслює, що такі дослідження можуть описати лише «ядро» електоратів кожної партії, а загальна картина є більш складною. Однак навіть такий обмежений результат здатний дати інформацію для розуміння конфігурації виборчого корпусу [12]. А втім, дослідження К.Г. Холодковського, як і його російських колег, демонструють, що розмежування електоратів пострадянських країн $є$ далеким від розвиненої та усвідомленої ідейно-політичної диференціації [12].

У дослідженнях Г. Дилигенського переконливо показана фрагментарність індивідуальної та групової свідомості, розмитість кордонів між соціально-психологічними групами $i$, як наслідок, нестійкість, мінливість багатьох уявлень і цінностей виборців [14]. 
Більш сучасні електоральні дослідження російських політичних психологів спрямовані зокрема на аналіз основних моделей електоральної активності і пошук соціально-психологічних факторів електоральної поведінки. Наприклад, дослідження К. Іваненко за інтегральний фактор, який містить все різноманіття оціночних і ціннісних установок, що впливають на електоральну поведінку, приймає громадську думку [15]. Автор уважає, що громадська думка $є$ не лише індикатором стану суспільства, але й регулятором тих процесів, які в ньому відбуваються. Під дією ціннісних орієнтацій і оціночних суджень, громадська думка впливає на електоральну поведінку. Тож для вивчення обох векторів впливу, К. Іваненко вивчав вплив на електоральну поведінку оціночних суджень суспільної думки стосовно якості державних інститутів, політичних сил, тощо та взаємозв'язок ціннісних орієнтацій та електоральної активності [15]. За результатами його дослідження, на електоральну активність громадян істотно впливає оцінка громадською думкою ефективності уряду, якості державного регулювання, політичної стабільності, ступеня відкритості і підзвітності держави. Велике значення мають установки громадської думки, пов'язані 3 довірою до парламенту, політиків і політичних партій, а також до самого інституту виборів. Важливим соціально-психологічним фактором активності виборців є значимість для громадської думки таких цінностей, як рівність можливостей, толерантність по відношенню до інших, самостійність у прийнятті рішень, верховенство закону. Проведене К. Іваненко дослідження показало, що взаємозв'язок оціночних i ціннісних установок громадської думки і електоральної активності носить нелінійний характер, передбачає існування оптимуму. Громадяни схильні брати участь в тих виборах які несуть реальний відчутний результат. В основі взаємозв'язку явища волевиявлення і реальної політики лежить пряма відповідальність держави перед суспільством [15].

Український політичний психолог і аналітик В. Рибаченко [16] на основі узагальнення досвіду виборів в Україні розробив власну соціально-психологічну типологію електорату, у якій підставою для типологізації виступає мотивація до голосування. Він виділяє 4 типи виборців переконані, мислячі, байдужі та продажні, які в свою чергу поділяються на 8 підтипів. Переконані виборці - на фанатів і зазомбованих, мислячі виборці - на аналітиків та пошуковців, байдужі виборці - на розчарованих та «пофігістів» та продажні виборці - на бідних і циніків. Відповідно до виділених груп виборців, автор типологізує i політиків.
Схожий підхід описаний українськими дослідниками К. Бура та О. Левцун. Вони класифікували психотипи політиків, які вступають у передвиборчу боротьбу, а не електорат, як такий. Автори впевнені, що в Україні голосують насамперед за особистість, а не за програму. А фахівців (психологів, політологів, іміджмейкерів, піарників, тощо) у свою чергу цікавить, які типи особистостей серед політиків найбільш сприятливо приймаються виборцями [17].

В основу дослідження К. Бура та О. Левцун було покладено типологію Майєрс-Бріггс (МВТІ), що грунтується на теорії К.-Г. Юнга [17]. Вони аналізували факти з біографії політика, його особистого життя та політичної діяльності, матеріали особистих інтерв'ю для 3МI та характеристики i оціночні висловлювання на адресу політика, надані знайомими 3 ним людьми. Результати аналізу ключових українських політиків були перекладені на результати опитування електоральних очікувань, щодо нового лідера [17].

Цікавим у межах нашого дослідницького інтересу $є$ підхід до типологізації електорату російського дослідника С. Хорошаєва. Він виділяє рефлексивну систему виборчої кампанії - тобто, систему учасників виборчої кампанії, наділених особливими позиціями, які багатократно відображають як фізичні процеси, так і їх відображення в свідомості учасників. Важкий потік відображень свідомостей учасників виборчої кампанії одна в одній автор називає рефлексивним процесом виборчої кампанії [18].

Відповідно до цього С. Хорошаєв будує свою класифікацію електоральних груп відносно операторів свідомості. Зокрема, він виділяє такі електоральні групи:

1. Виборців лише зі своєю думкою. Трапляється досить рідко. Являють собою скоріше ідеальний, аніж реальний тип електорату.

2. Найпростіший виборець. Найпростіший iз погляду рефлексивної структури виборець має власну думку про процеси, що відбуваються навколо нього, і ці уявлення недоторкані думкою навколишніх людей.

3. Виборець-соліпсоїд. Якщо найпростіший виборець бачить перед собою процеси, що насправді відбуваються навколо, то перед виборцем-соліпсоїдом знаходиться не дійсність, а власна система уявлень, відображена ним самим. Реальність з боку виборця завжди виступає лише як елемент його внутрішнього світу.

4. Виборець, який усвідомлює двічі. Має комбінований тип свідомості, що об'єднує моделі найпростішого виборця і виборця-соліпсоїда. Факт відображення сам одночасно відображується.

5. Виборець під абсолютним впливом. Патологічна ситуація, коли виборець не має власної 
думки. Світ, що лежить перед виборцем, - це феномен, що протікає всередині політтехнолога або іншої особи, що має над ним абсолютний вплив.

6. Виборець-раціоналіст (максимінний виборець). Виборець, який приймає найкраще для себе рішення, виходячи переможцем у грі. Людина, яка голосує за принципом обміну і веде виборчій торг.

7. Виборець 3 симетричною рефлексивною структурою. Виборець, який усвідомлює, що над ним проводяться маніпуляції і намагається прорахувати наступні дії політтехнолога.

Така картина, на думку автора, склалася в електоральному полі через «розпіарювання» виборчих технологій. Саме це сприяло максимінному замиканню рефлексії виборців i, як наслідок, формуванню абсентеїстської позиції електорату [18].

Висновки. Отже, базуючись на класичних теоріях електоральної поведінки, в сучасній науці було сформовано кілька підходів до типологізації електорату, де критеріями для типологізації виступають політичні симпатії та орієнтації, міра знайомства 3 програмами кандидатів і агітаційною продукцією, зміна наміру голосувати у ході передвиборчої кампанії (В. Комаровський), ступінь включеності у виборчий процес (В. Зарубін), стійкість електоральних орієнтацій (П. Лазерфельд), міра власної вигоди від результатів виборів (М. Фіорина), чутливість до базових стратегій виборчих кампаній (О. Петров) тощо.

Соціально-психологічні критерії типологізації виборців закладали послідовники Мічіганської школи і А. Кемпбелл. Вони виділяли партійну ідентифікацію, ставлення до поточних подій та почуття до кандидата як ключові підстави для типологізації.

Спроби типологізувати електорат за психологічними характеристиками у роботах багатьох вчених носять фрагментарний характер, найчастіше враховуючи лише одну з цих характеристик. Так, В. Рибаченко типологізує виборців за ступенем переконаності у правильності власного політичного вибору, рівнем критичності сприйняття та ступенем політичної байдужості. С. Хорошаєв розробляє типологію на підставі операторів свідомості та усвідомлення виборцями політичних процесів. Однак найбільш поширеною в країнах пострадянського простору й досі залишається типологізація виборців на підставі соціально-демографічних характеристик. Групи виділяються на основі віку, статі, рівня освіти, регіону проживання та типу поселення, політичної приналежності, електоральних симпатій, тощо. Серед досліджень, виконаних в даному підході найвагомішими є дослідження Є.Г. Галицької, А.А. Чернякова, М. Григорьєва, К.Г. Холодковського та ін.

Додаткової уваги потребує розроблення інтегративного підходу до дослідження електорату та його типологізації, який не буде залежати від поточного політичного ландшафту і враховуватиме індивідуальні особливості виборців. У подальших дослідженнях доцільно було б розширити коло критеріїв для типологізації виборців 3 об'єктивних (вік, стать, регіон проживання та тип поселення, достаток, освіта, форма політичної участі) на суб'єктивні (особистісні, ціннісні, мотиваційні, когнітивні та інші сталі особливості). Великий науковий та практичний інтерес представляє пошук предикторів електорального вибору та тих особливостей виборців, які матимуть прогностичний потенціал. Наявність системних уявлень про типи виборців та їхні особистісні профілі допоможе змістовно підійти до розуміння електорату та стане підставою для налагодження конструктивної взаємодії у системі держава-суспільство-особистість.

\section{ЛIТЕРАТУРА}

1. Комаровский В.С. Типология избирателей // Социологические исследования. № 1., М.,1990. С. $42-47$.

2. Зарубин В.Г. Элективное действие и формирование корпуса российских избирателей (опыт социологического анализа): Автореф. дис. д. соц. наук. / В.Г. Зарубин, СПб., 1998.

3. Lasarsfeld, P. The People?s Choice [Text] / P. Lasarsfeld. N.Y., 1969.

4. Фіорина М. Ретроспективне голосування в американських національних виборах, Нью Хевен: видавництво Сльського університету, 1981. 389 с.

5. Шемелин А.В. Типология электорального поведения на выборах в органы государственной власти в России и за рубежом / А.В. Шемелин, С.В. Бородина: Вестник Санкт-Петербургского университета МВД России, № 4. 2006. С. 166-170.

6. Петров О. Стратегії політичних сил на парламентських виборах 2006 року / О. Петров // Політичний менеджмент, 2006. № 1. С. 18-26

7. Галицкая Е.Г. Электоральные группы ведущих политиков России / Е.Г. Галицкая, А.А. Черняков: Фонд "Общественное мнение". 1999. [Електронний ресурс]. Режим доступу: http://bd.fom.ru/report/ cat/el_rat/o905720

8. Григорьев М. Комплексная методика «Реконфигурация электорального поля» // По материалам 2-й всероссийской научно-практической конференции «Новые избирательные технологии: особенности региональных выборов» // Психология и бизнес. 2009. 
9. Олпорт Г. Личность в психологии / Г. Олпорт, М.: КСП, СПб: "Ювента", 1998. 345 с.

10. Полторак В.А. Избирательные кампании: научный подход к организации / В. А. Полторак, О. В. Петров, К.: Знания Украины, 2004. 315 с.

11. Вишняк О.І. Динаміка ідеологічних орієнтацій і електоральна поведінка населення України (1994-2000рр.) // Українське суспільство моніторинг - 2000 р. Інформаційно-аналітичні матеріали, К.: IC НАНУ, 2000. С.129-135.

12. Холодковский К.Г. Социально-психологическая дифференциация российского населения и процесс формирования партий // Полис, 2001. №5.

13. Гудков Л. Российские выборы: время «серых» // Б. Дубин, Л.Гудков / Мониторинг общественного мнения: Экономическиеи социальные перемены. 2000. № 2. С. 17-29.

14. Дилигенский Г.Г. Дифференциация или фрагментация? (О политическом сознании в России), М.: МЭиМО, 1999. № 9, 10.

15. Иваненко К.А. Социально-психологические детерминанты электорального поведения избирателя / Современные социально-психологические исследования: Вестник РУДН, серия «Психология и педагогика», 2013. № 3.

16. Рибаченко В.Ф. Типи виборців та типи кандидатів: за кого голосувати? [Електронний ресурс]. Режим доступу: https://dif.org.ua/article/tipi-vibortsiv-ta-tipi-kandidativ-za-kogo-golosuvati

17. Бура К., Левцун О. Командир, Підприємець, Артист та інші: психотипи політиків, які вступають у передвиборну боротьбу. [Электроннный ресурс]. Режим доступу: http://newukraineinstitute.org/ media/news/875/file/Психотипи.pdf

18. Хорошаев С.В. Класификация электоральных групп // Социология власти, 2007. №6.

\section{REFERENCES}

1. Komarovsky V.S. (1990) Typologiya izbirateley [Typology of Voters]. Moscow: Sociological Research. No. 1 [in Russian].

2. Zarubin V.G. (1998) Elektivnoye deystviye i formirovaniye korpusa rossiyskikh izbirateley (opyt sotsiologicheskogo analiza) [Elective action and the formation of the corps of Russian voters (the experience of sociological analysis)]. St. Petersburg: dissertation abstract of Doctor of Sociological Sciences [in Russian].

3. Lasarsfeld, P. (1969) The People's Choice: How the Voter Makes Up His Mind in a Presidential Campaign, N.Y: Columbia University Press. [in English]

4. Fiorina M. (1981) Retrospective voting in American national elections, New Haven: Yale University Press [in English].

5. Shemelin A.V. (2006) Tipologiya elektoral'nogo povedeniya na vyborakh v organy gosudarstvennoy vlasti $v$ Rossii i za rubezhom [Typology of Electoral Behavior at Elections to Government Bodies in Russia and Abroad]. St. Petersburg: publishing office of the St. Petersburg University of the Ministry of Internal Affairs of Russia [in Russian].

6. Petrov O. (2006) Stratehiyi politychnykh syl na parlaments'kykh vyborakh 2006 roku [Strategy of political forces at parliamentary elections in 2006]. Kyiv: Political management No. 1 [in Ukrainian].

7. Galitskaya E.G. (1999) Elektoral'nyye gruppy vedushchikh politikov Rossii [Electoral groups of leading Russian politicians]. Moscow: Public Opinion Foundation [in Russian].

8. Grigoriev M. (2009) Kompleksnaya metodika «Rekonfiguratsiya elektoral'nogo polya» [Complex methodology "Reconfiguration of the electoral field"]. Moscow: Psychology and business [in Russian].

9. Allport G. (1998) Lichnost'v psikhologii [Personality in psychology]. Moscow: KSP, St. Petersburg: "Juventa" [in Russian].

10. Poltorak V.A. (2004) Izbiratel'nyye kampanii: nauchnyy podkhod k organizatsii [Election campaigns: a scientific approach to organization]. Kyiv: Knowledge of Ukraine [in Russian].

11. Vishnyak O.I. (2000) Dynamika ideolohichnykh oriyentatsiy i elektoral'na povedinka naselennya Ukrayiny (1994-2000) [Dynamics of ideological organizations and electoral behavior of the population of Ukraine (1994-2000)]. Kyiv: Institute of Sociology of the National Academy of Sciences of Ukraine [in Ukrainian].

12. Kholodkovsky K.G. (2001) Sotsial'no-psikhologicheskaya differentsiatsiya rossiyskogo naseleniya i protsess formirovaniya partiy [Socio-psychological differentiation of the Russian population and the process of party formation]. Moscow: Polis [in Russian].

13. Gudkov L. (2000) Rossiyskiye vybory: vremya «serykh» [Russian elections: the time of the "gray"]. Moscow: Monitoring of public opinion: Economic and social changes [in Russian].

14. Diligensky G.G. (1999) Differentsiatsiya ili fragmentatsiya? (O politicheskom soznanii v Rossii) [Differentiation or fragmentation? (On political consciousness in Russia)]. Moscow: World economy and international relations [in Russian]. 
15. Ivanenko K.A. (2013) Sotsial'no-psikhologicheskiye determinanty elektoral'nogo povedeniya izbiratelya [Socio-psychological determinants of the electoral behavior of the voter]. Moscow: Publishing house of the RUDN University [in Russian].

16. Ribachenko V.F. (2012) Typy vybortsiv ta typy kandydativ: za koho holosuvaty? [Typy vybortsiv ta typy kandydativ: za koho holosuvaty?]. Kyiv: Democratic Initiatives Foundation Ilka Kucheriva [in Ukrainian].

17. Bura K., Levtsun O. (2018) Pidpryyemets', Artyst ta inshi: psykhotypy politykiv, yaki vstupayut' u peredvybornu borot'bu [Pidpryyemets', Artyst ta inshi: psykhotypy politykiv, yaki vstupayut' u peredvybornu borot'bu]. Kyiv: New Ukraine Institute [in Ukrainian].

18. Khoroshaev S.V. (2007) Klassifikatsiya elektoral'nykh grupp [Classification of electoral groups]. Moscow: Sociology of power [in Russian]. 